\title{
Budgeting in small manufacturing firms in South Africa
}

\author{
J.C. Ford ${ }^{*}$ \\ Graduate School of Business Administration, University of the Witwatersrand, P.O. Box 98, Wits, 2000 \\ Republic of South Africa \\ M. Lurie \\ P.O. Box 31170, Braamfontein, 2017 Republic of South Africa
}

Accepted September 1988

\begin{abstract}
This paper reports on a general investigation into budgeting in small manufacturing firms in South Africa. The study was undertaken using 18 semi-formal interviews and 175 questionnaires addressed to the Chief Executive Officers (CEOs) of small manufacturing firms in six industry sectors in the greater Johannesburg region. The 63 usable responses (a response rate of $36 \%$ ) were analysed using the SAS statistical package. Several results and ccnclusions were reached. A wide range of budgetary processes and procedures are used by small manufacturing firms. Budgeting is short-term, informal, simple and flexible, and is considered an essential element of management. There is room for much improvement in certain areas of budgeting. Although accounting reports are perceived to be adequate, CEOs may lack the necessary knowledge to develop more effective reporting systems. The degree of budgeting used is probably influenced by the nature of the business, and the background and training of the CEO. CEOs are completely involved in budgeting, but there is little participation by managers and staff. The major benefits of budgeting are perceived to be its use in planning and control, particularly of cash, and the major problems relate to the uncertainty of future conditions.
\end{abstract}

\begin{abstract}
Hierdie artikel handel oor 'n algemene ondersoek na die rol van begrotings in klein Suid-Afrikaanse vervaardigingsondernemings. Die ondersoek is gebaseer op 18 semi-formele onderhoude en 175 vraelyste wat aan die hoof uitvoerende amptenare van klein vervaardigingsondernemings in ses industriële sektore in die Johannesburgstreek gestuur is. Die 63 bruikbare terugvoerings (36\% van die totaal) is $\mathrm{m}$. b.v. die SASstatistiese paket ontleed en verskeie gevolgtrekkings is gemaak. Die betrokke ondernemings gebruik ' $n$ wye verskeidenheid van begrotingsprosesse en -prosedures, en die begrotings is oor die algemeen kort-termyn, informeel, eenvoudig en aanpasbaar van aard. Alhoewel begrotings as 'n essensiële element van bestuur beskou word, is daar heelwat ruimte vir verbetering. Die mate waarin begrotings gebruik word, word waarskynlik beïnvloed deur die aard van die onderneming sowel as die agtergrond van die hoof uitvoerende amptenaar. Alhoewel die hoof uitvoerende amptenaar volledig betrokke is by die begrotingsproses, is daar min deelname deur ander bestuurders en personeel. Die bydrae wat begrotings lewer tot beplanning en beheer, veral van die kontantvloei, word as die grootste voordeel daarvan beskou. Die grootste probleem met begrotings hou verband met die onsekerheid oor toekomstige gebeure.
\end{abstract}

*To whom correspondence should be addressed

\section{Introduction}

Essentially, the work of management involves four broad functions : planning, organizing and directing, controlling and decision making. These functions are carried on more or less simultaneously and often under considerable stress, urgency and pressure (Garrison, 1985). Budgeting is a systematic and formalized approach to accomplishing these responsibilities of management. It assists managers, in an organized and comprehensive manner, to carry out all four of these functions. When implemented properly, budgeting becomes a vital foundation for the management of an organization. As managerial skills are one of the most important key success factors in small business (Ibrahim \& Goodwin, 1986), it is essential that small firms engage in efficient and effective budgetary procedures. Effective budgeting means effective management, and effective management leads to business success.

All firms should have a basic budgeting system which can be used for planning and control. Time should be taken in advance of expenditure to decide on what and where to spend cash (De Mong \& Croll, 1981). For budgeting to succeed, it requires top management involvement and support, a clear definition of long-term objectives, and full acceptance and involvement of line managers concerned (Campbell, 1985). The system should be easy to use, understand, and maintain, and should be flexible and cost effective (De Mong \& Croll, 1981). Several key studies suggest that small firms benefit from planning activity which should be substantive, relatively informal, incorporate outsider input and be concrete in addressing objectives (Robinson, Salem, Logan \& Pearce, 1986).

As with other areas of management, budgeting in small firms is different from the complicated and formalized procedures in large firms. Dewhurst (1983) points out that financial management, of which budgeting is an important part, is different for small firms in three ways:

- First, the skills must generally be exercised by one person, the owner-manager.

- Second, the owner-manager will usually not have any particular expertise, let alone professional qualifications in the area.

- Third, if incorrect financial decisions are made, it is he or she, as the owner, who will suffer.

There are a variety of approaches to budgeting. Management should use the type or types that best suit 
their needs for planning and control purposes (Ray, 1974). Differences in budget structures and processes largely determine the effectiveness of budgeting and whether it accomplishes management's objectives (Churchill, 1984).

\section{Budgeting in small businesses}

The importance of the small business community is widely recognized and documented. Ibrahim \& Goodwin (1986) state that the success of the small business sector is crucial to both the stability and health of the economy of the United States and Canada. They indicate that $\mathbf{9 7 \%}$ of all businesses are categorized as small, that they produce $45 \%$ of the Gross National Product and create $67 \%$ of new jobs. Robinson \& Pearce (1984) report that small businesses employ over $60 \%$ of the private workforce in the United States. In addition, $25 \%$ of major innovations between 1953 and 1973 came from firms with less than 100 employees. In South Africa, the President's Council : Committee for Economic Affairs (1985) has emphasized the crucial role the small business community has to play in employment creation. Recent moves by government to reduce the legal restrictions on small business, and to encourage small business development, underline the recognition of the importance of small business. Williams (1985) notes that a small business community helps to maintain a free market economy by developing markets which are too small to interest larger corporations.

This paper reports on the use of budgeting in small manufacturing firms in South Africa. In particular, a number of subsidiary problems, dealing with specific areas of budgeting in small firms are highlighted:

- What budgetary processes and procedures should exist in small manufacturing firms?

- What budgetary processes and procedures do exist in respondent organizations?

- How important is budgeting perceived to be?

- Are performance and accounting reports perceived to be adequate?

- Will factors such as the complexity of the business and the background and training of the CEO influence the degree of budgeting used?

- Is there commitment to and participation in budgeting by the CEO and managers?

- What are the benefits and problems of budgeting?

- What recommendations can be made concerning budgeting in small manufacturing firms that are relevant to South African organizations?

\section{Reasons for the research}

The research was conducted for a number of reasons:

- The vital importance of budgeting as a method of management is stressed throughout the literature.

- The significance of the small business sector is such that any research which will benefit this sector is of great importance.

- Very little research has been undertaken in this area in the South African context.
- Personal experience of the authors has indicated the paucity of modern management techniques amongst managers of small firms in South Africa.

- The increasing complexity and competitiveness of the South African business environment requires an increasingly sophisticated approach to the planning and control of small firms.

The objectives of the research reported on were broad in scope, with no detailed examination of any particular aspect of budgeting in small manufacturing firms. It should be regarded as a general exploratory study providing information for further, more in depth, investigation into selected areas related to the subject. The research was also general in the sense that it covered a range of industry sectors.

\section{Hypotheses tested}

On the basis of an intensive literature study, the semiformal interviews conducted, and from the authors' observations of practices in small firms in South Africa, the following hypotheses were postulated:

Hypothesis 1: Budgeting is perceived to be important in small manufacturing firms.

Hypothesis 2: Accounting reports are perceived to be adequate in small manufacturing firms.

Hypothesis 3: There is a positive correlation between the nature of the business and the degree of budgeting used.

Hypothesis 4: There is a positive correlation between the background and training of the CEO in budgeting and the degree of budgeting used.

Hypothesis 5: Chief Executive Officers of small manufacturing firms are committed to and participate in budgeting.

Hypothesis 6: Managers and staff of small manufacturing firms are committed to and participate in budgeting.

\section{Research method}

A two-stage approach to the gathering of data was used. The first stage consisted of semi-formal interviews of a small sample of companies to establish and refine the major themes and issues to be investigated. The second stage consisted of a questionnaire, which was delivered to each of the companies in the population in order to save time and improve the response rate. It was decided that the questionnaires should be addressed to the CEOs, on the basis that in general they were the most suitably qualified individuals within the organizations (of this size) to complete them.

Names of companies were obtained from the Bureau of Market Research, University of South Africa. The Bureau claims to have on record every company in South Africa, with certain details and statistics on each company. It was felt that the records were comprehensive, and at least were representative of South African companies. In addition, records were maintained on industry, number of employees, whether the 
company was independently owned or not, and physical and postal addresses.

It was decided to focus on manufacturing firms, as due to the greater complexity of that type of business, budgeting is especially appropriate (Dearden, 1963). There is no one generally accepted definition of a small business. The literature indicates that the criteria to delineate a small business include size, number of employees, sales volume, asset size, type of customers and capital requirements (Ibrahim \& Goodwin, 1986). It was decided to define a small manufacturing firm as one that was independently owned, and that had between ten and one hundred employees. The bottom limit was established to eliminate the really small firms that invariably have very few budgeting practices. Six industries were chosen, to give greater generality and wider applicability to the results. The industries were clothing, wooden furniture, metal furniture, stationery, paint and varnishes, and plastic products. It was decided to limit the population to the greater Johannesburg area, to enable questionnaires to be sent to the entire population, and to improve accessability to respondent companies.

There were 175 firms falling within these parameters (independently owned, ten to one hundred employees, in one of the six industries, within the greater Johannesburg area). A $10 \%$ sample (18 firms) was chosen, using systematic sampling, for the semi-formal interviews. All 175 firms in the population were then contacted by telephone, to ascertain whether or not they would be willing to complete the questionnaires.

Questionnaires were delivered to each company which responded positively.

\section{The semi-formal interview/questionnaire development}

The semi-formal interview consisted of seven background questions and ten free response questions on budgeting. The interviews were structured to last approximately thirty minutes to one hour. The questions were generally open-ended, to encourage comprehensive. responses which would cover all aspects of budgeting in small manufacturing firms. Anonymity was necessary, as managers would not respond unless this was so. In most cases the General Manager was interviewed. The questions were compiled from a general review of the literature and from personal experience, to cover all issues in budgeting. The interviews provided an important insight into the major themes and issues in budgeting in small manufacturing firms, and led to certain questions being discarded for the questionnaire, and other questions being included (both instruments are available from the writers).

The questionnaire consisted of nine background questions, and 48 questions on budgeting. The questions were structured and closed-ended, developed specifically with the objectives of the study in mind. The questions appear to be unambiguous and simple. A small pilot study using colleagues indicated that the questionnaire could be completed in approximately 15 minutes, which was considered reasonable for this type of study. Company and personal anonymity were assured. Questions were compiled from an intensive review of the literature, and by analysis of responses to the semi-formal interviews.

\section{Data analysis}

A statistical analysis of responses (ideally suited to analysing data from a large number of questionnaires consisting of several closed questions) was undertaken. The SAS statistical package on the Wits University mainframe computer was used. The SAS procedures used included PROC FREQ (which shows the distribution of a variable's value), PROC MEANS (which computes the arithmetic mean, standard deviation and other summary statistics), PROC CHART and PROC PLOT (which depict graphic representations of variables), and PROC CORR (used to measure the strength of the relationship between two variables).

Unless otherwise stated, tests of the hypotheses were all carried out at the $5 \%$ significance level, one sided tests.

\section{Response rates}

Of 175 companies contacted by telephone, 63 agreed to participate in the research (a response rate of $36 \%$ ). Questionnaires were delivered to these companies, and respondents assisted with any queries on completing the questionnaires. This ensured that all 63 companies completed the questionnaires correctly. Thus a random sample of 63 companies is used to answer the research questions. This response rate is considered adequate to allow meaningful analysis.

Table 1 Number of companies in each sector

\begin{tabular}{lcc}
\hline Industry sector & Frequency & $\%$ \\
\hline Clothing & 9 & 14,2 \\
Metal furniture & 10 & 15,9 \\
Paints and varnishes & 10 & 15,9 \\
Plastic products & 10 & 15,9 \\
Stationery & 14 & 22,2 \\
Wooden furniture & 10 & 15,9 \\
Total & 63 & 100,0 \\
\hline
\end{tabular}

Table 2 Age of respondent companies

\begin{tabular}{lcc}
\hline Age & Frequency & $\%$ \\
\hline 5 years or less & 9 & 14,3 \\
$6-10$ & 8 & 12,7 \\
$11-15$ & 16 & 25,4 \\
$16-20$ & 9 & 14,3 \\
$21-25$ & 14 & 22,2 \\
$26-30$ & 5 & 7,9 \\
$31-35$ & 2 & 3,2 \\
Total & 63 & 100,0 \\
\hline
\end{tabular}


Companies from all six industry sectors chosen participated in the study. The number of companies in each sector are indicated in Table 1.

Over half the respondents were 15 years old or less (See Table 2), indicating the more precarious position of small, independently owned manufacturing firms compared to large firms.

Respondent companies are also of diverse size (see Table 3).

\section{Budgetary processes and procedures used}

Of the ten budgeting activities, the number of activities carried out by each is indicated in Table 4 .

Every company carried out at least four budgeting activities, and half carry out between four and seven activities regularly. Table 4 clearly shows that seven activities are carried out most often, with decidedly fewer companies performing all ten, or only four, activities. The percentage of companies carrying out each of the activities is as indicated in Table 5.

Thus every company plans cash paid and received, while only $7,9 \%$ of companies forecast balance sheets. Only $27,0 \%$ of respondent companies compile budgets for separate product lines thus indicating that most companies prepare budgets only for the firm as a whole.

The average time period over which most companies carry out budgeting activities in one month is shown in Figure 1. Some companies however, budget on average only for the next one to two weeks, while other companies budget on average for the next three to six months.

As regards the level of formality, all the respondent companies describe their budgets as simple and flexible.

Table 3 Tumover of respondent companies

\begin{tabular}{lcc}
\hline Turnover & Frequency & $\%$ \\
\hline Less than R500 000 p.a. & 12 & 19,0 \\
R500 001 - R1 000 000 & 8 & 12,7 \\
R1 000 001 - R3 000 000 & 18 & 28,6 \\
R3 000 001 - R5 000 000 & 12 & 19,0 \\
More than R5000 000 & 13 & 20,7 \\
Total & 63 & 100,0 \\
\hline
\end{tabular}

Table 4 Budgeting activities effected by each company

\begin{tabular}{lcr}
\hline Number of budgeting activities & Frequency & $\%$ \\
\hline 4 & 4 & 6,3 \\
5 & 8 & 12,7 \\
6 & 10 & 15,9 \\
7 & 18 & 28,6 \\
8 & 10 & 15,9 \\
9 & 10 & 15,9 \\
10 & 3 & 4,7 \\
Total & 63 & 100,0 \\
\hline
\end{tabular}

Table 5 Analysis of companies carrying out each activity

\begin{tabular}{lc}
\hline Budgeting activity & $\begin{array}{c}\text { \% of companies } \\
\text { performing } \\
\text { that activity }\end{array}$ \\
\hline 1. Plan cash paid and received & 100,0 \\
2. Forecast sales & 96,8 \\
3. Plan units of production & 96,8 \\
4. Plan raw materials & 96,8 \\
5. Forecast income statement & 93,7 \\
6. Plan labour expenses & 74,6 \\
7. Plan overhead expenses & 60,3 \\
8. Plan capital expenditure & 47,6 \\
9. Plan sales and admin expenses & 27,0 \\
10. Forecast balance sheet & 7,9 \\
\hline
\end{tabular}

Table 6 Number of budgeting activities carried out in writing

\begin{tabular}{lcr}
\hline Number of activities written & Frequency & $\%$ \\
\hline 0 & 5 & 7,9 \\
1 & 4 & 6,3 \\
2 & 9 & 14,3 \\
3 & 7 & 11,2 \\
4 & 13 & 20,6 \\
5 & 8 & 12,7 \\
6 & 7 & 11,2 \\
7 & 5 & 7,9 \\
8 & 4 & 6,3 \\
9 & 1 & 1,6 \\
Total & 63 & 100,0 \\
\hline
\end{tabular}

Most $(66,7 \%)$ draw up budgets in a regular, standardized manner. The level of formality of budgeting can be gauged from the number of budgeting activities each firm carries out in writing (see Table 6).

Sixty per cent of the companies carry out four or less budgeting activities in writing. This tends to confirm a high degree of informality in budgeting.

The starting point of the budgeting process is the development of goals and strategies. Only $7,9 \%$ of companies have clear, written, specific objectives for the business. However, $54,0 \%$ believe they have a clear, consistent strategy. Most companies see their budget goals as loose and attainable $(61,9 \%)$, and most CEOs believe that budget goals should be easy to attain $(65,1 \%)$.

While $52,4 \%$ of companies run their accounting systems on computer, only $25,4 \%$ use a computer in budgeting. In addition, only $46 \%$ of those who use computers feel that introducing a computer led to a major improvement in accounting reports and budgets.

There is varied use of the different budgeting techniques; $34,9 \%$ of companies perform a rolling budgetary process. Only $14,3 \%$ carry out some form of zero base 


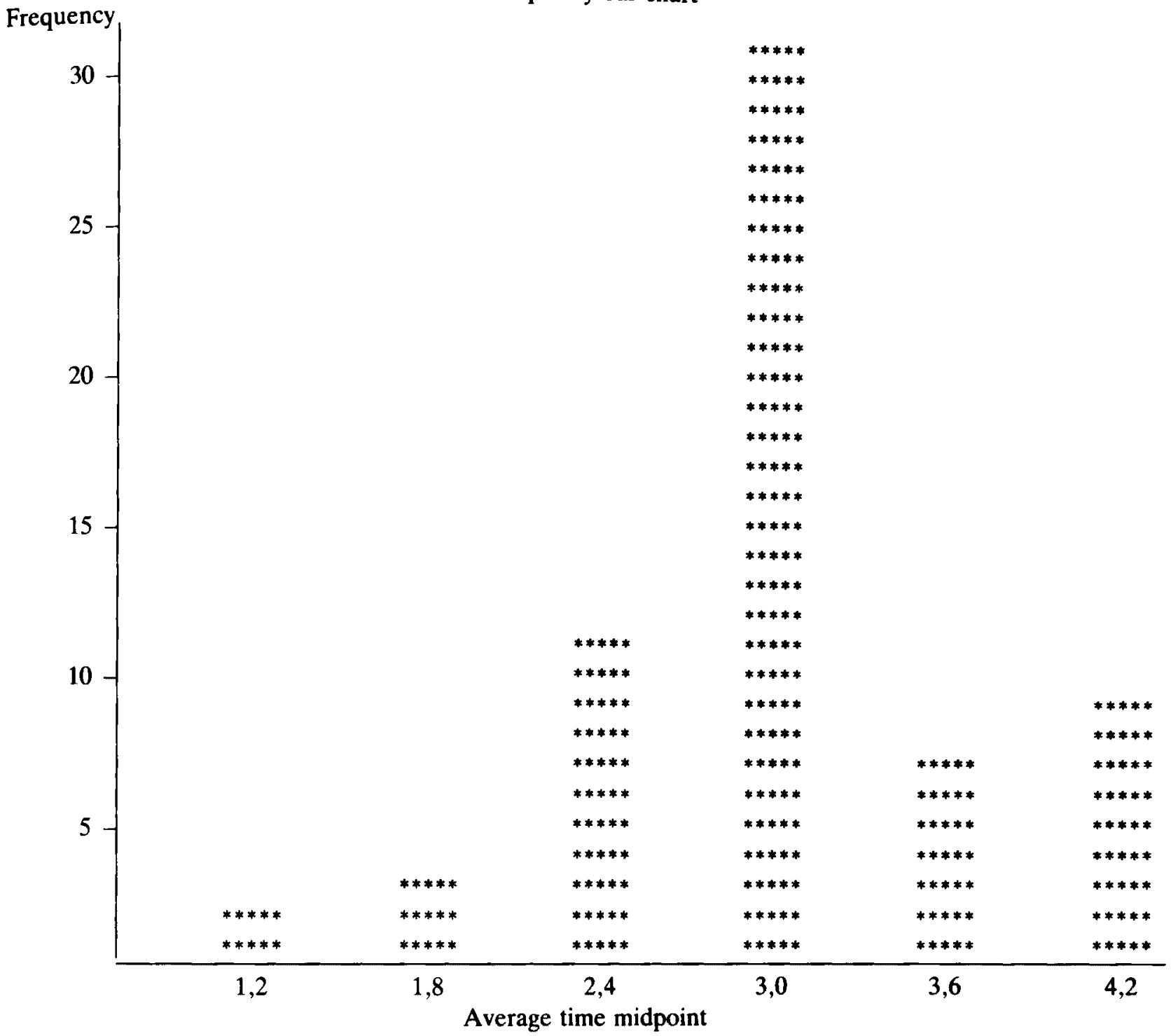

Figure 1 Average budget periods $-1=$ one week; $2=$ two weeks; $3=$ one month; $4=$ three months

budgeting. However, all companies use flexible budgets. In addition, no companies use mathematical techniques to help forecast future sales.

Budgeting is used almost equally for planning and for control; $54,0 \%$ of companies budget mainly in order to plan for the future, while $46,0 \%$ budget mainly in order to control the business.

\section{Perceived importance of budgeting}

When the frequencies of the various measures of importance are totalled, the overall results are as per Table 7.

Hypothesis 1 proposes that budgeting is perceived to be important in small manufacturing firms. To test this hypothesis, the frequency that 'Very important' is mentioned must be compared with the frequencies that other measures are mentioned. If it can be shown that the hypothesis holds for the most frequently mentioned group (in this case 'Activity not carried out'), then the hypothesis must be valid for the other groups as well.

With a $5 \%$ significance level, the decision rule is:

Reject $\mathbf{H}_{0}$ if $Z<1,64$; otherwise do not reject $\mathbf{H}_{0}$.
Table 7 Totalled frequencies of the various measures of importance

\begin{tabular}{lcr}
\hline & $\begin{array}{c}\text { Total no of times } \\
\text { mentioned }\end{array}$ & $\%$ \\
\hline Very important & 350 & 55,6 \\
Average importance & 64 & 10,2 \\
Not very important & 28 & 4,4 \\
Activity not carried out & 188 & 29,8 \\
Total & 630 & 100,0 \\
\hline
\end{tabular}

Berenson and Levine (1983) state the formula for $Z$ for a large sample as:

$$
Z=\frac{\left(\text { Veryimp } \%-\text { Not done } \% *(n)^{1 / 2}\right.}{(\text { Notdone } \% *(1-\text { Notdone } \%))_{1 / 2}}
$$

Where $n=63$ is the sample size. Substituting values into the above formula gives $Z=4,477$. Therefore the null hypothesis is accepted. Since Notdone \% was the 
largest proportion compared with Veryimp \%, the hypothesis can be accepted for all groups.

Five other questions in the questionnaire relate to the perceived importance of budgeting. Respondents indicate a perception of budgeting as important if they answer that they:

1. Really do run the business through the budgeting system.

2. Feel it is important for motivation that managers and staff get feedback on their performance compared to goals.

3. Feel it is important to set clear goals and objectives in order to motivate managers and staff.

4. Feel that a budgeting system is very important.

5. Believe that small manufacturing firms that budget effectively are more profitable than those that do not budget.

To test hypothesis 1 , the proportion of responses indicating a perception of budgeting as important must be compared with the proportion indicating a perception of budgeting as not important.

Thus the null hypothesis is $\mathrm{H}_{0}:$ Yes $\%>$ No $\%$ and the alternative hypothesis is $\mathrm{H}_{2}$ : Yes $\% \leqslant$ No $\%$ For a 5\% significance level, the decision rule is: Reject $\mathrm{H}_{0}$ if $Z<1,64$; otherwise accept $\mathrm{H}_{0}$.

The formula for $Z$ for a large sample is:

$Z=\frac{(\text { Yes } \%-\text { No })^{*}(n)^{1 / 2}}{\left(\text { No } \%^{*}(1-\text { No } \%)\right) ~ 1 / 2}$

where $n=63$ is the sample size.

For the 5 questions, the proportion of Yes and No answers, and the $Z$ values are as indicated in Table 8 .

Thus the hypothesis is valid for four of the questions. The $100 \%$ positive response to 'A budgeting system is very important' indicates that the hypothesis may be accepted with a very high degree of confidence that it is correct.

\section{Perceived adequacy of accounting reports}

Figure 2 shows that $52,4 \%$ of companies receive two accounting reports regularly, and the other $47,6 \%$ receive three accounting reports regularly. The two reports that all companies receive are an income statement and balance sheet. Figure 3 shows that most companies receive accounting reports monthly. Half the companies $(49,25)$ have accounting reports that compare actual results with budgets. Only $12,7 \%$ however, give

\section{Table 8 Perception of importance of budgeting}

\begin{tabular}{lrcc}
\hline Question & Yes \% & No \% & $Z$ \\
\hline 1. Run business through budgeting system & 60,3 & 39,7 & 3,342 \\
2. Feedback compared to goals & 68,3 & 31,7 & 6,243 \\
3. Set clear goals for motivation & 47,6 & 52,4 & $-0,763$ \\
4. Budgeting very important & 100,0 & 0 & \\
5. Firms are more profitable with budgeting & 74,6 & 25,4 & 8,971 \\
\hline
\end{tabular}

Frequency bar chart

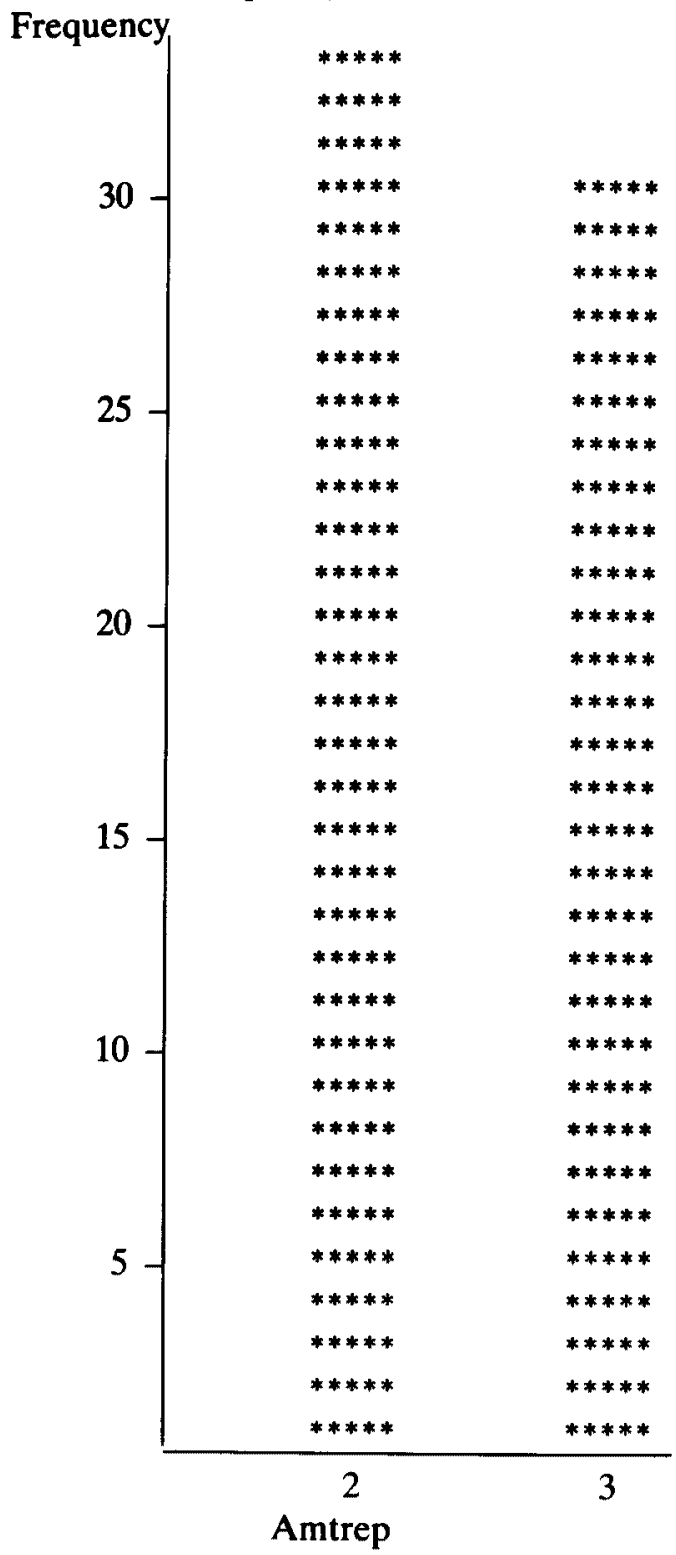

Figure 2 Number of accounting reports

accounting reports to each manager relevant to his or her area of responsibility. In addition, only $38,1 \%$ have accounting reports tailored to fit the needs of the budgeting system.

Three questions relate to the perceived adequacy of accounting reports. Respondents indicate a perception of accounting reports as adequate if they answer that:

1. Accounting reports are received within a few days of the end of the period.

2. Accounting reports provide the information needed to make effective decisions.

3. Action is taken in response to the information provided in accounting reports.

Hypothesis 2 proposes that accounting reports are perceived to be adequate in small manufacturing firms. To test this hypothesis, the proportion of responses indicating a perception of accounting reports as adequate must be compared with the proportion indicating a perception of accounting reports as inadequate. 


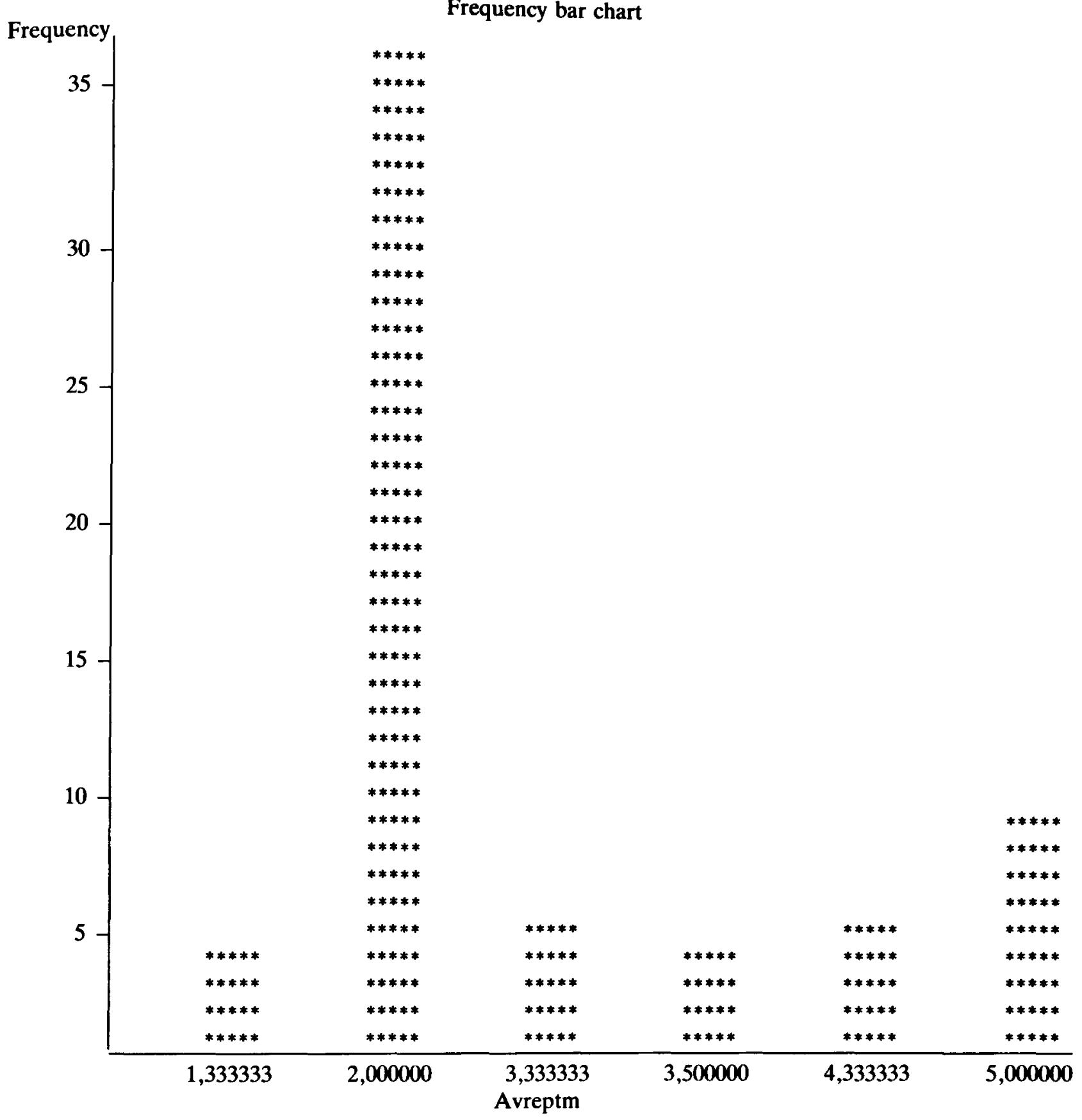

Figure 3 Average period of accounting reports $-1=$ one week; $2=$ one month; $3=$ three months; $4=$ six months; $5=$ one year

The null hypothesis is

$$
\mathrm{H}_{0}: \text { Yes } \%>\text { No \% }
$$

and the alternative hypothesis is

$$
\mathrm{H}_{2}: \text { Yes } \%<\text { No \%. }
$$

For the three questions, the proportion of Yes and No answers, and the $Z$ values, are as indicated in Table 9.

Thus the hypothesis is valid for all three questions. The large $Z$ values indicate that the hypothesis may be accepted with a very high degree of confidence that it is correct.

\section{Correlation between nature of the business and degree of budgeting used}

Hypothesis 3 proposes that there is a positive correlation between the nature of the business and the degree of
Table 9 Analysis of perceived adequacy of accounting reports

\begin{tabular}{llll}
\hline Question & Yes $\%$ & No \% & $Z$ \\
\hline 1. Reports received within a few days & 77,8 & 22,2 & 10,62 \\
2. Reports provide needed information & 85,7 & 14,3 & 16,189 \\
3. Action is taken in response to reports & 77,8 & 22,2 & 10,62
\end{tabular}

budgeting used. The criteria were defined which, based on the literature review and semi-formal interviews, would seem to influence the degree of budgeting used. The criteria are as follows:

1. Turnover greater than average turnover

2. Number of customers greater than average 
3. Number of monthly orders greater than average

4. Number of products greater than average

5. Number of employees greater than average

6. Lead time on raw material greater than average

7. Industry defined as stable

8. Use of foreign exchange

9. Normally make-for-stock not, make-to-order

10. Normally make regular products, not specials.

Average is defined as the sample average. It is proposed that the more criteria a firm complies with, the greater the degree of budgeting used. The degree of budgeting used is measured by the number of budgeting activities the firm carries out.

To test the hypothesis, the nature of the business (number of criteria applicable) was correlated with the number of budgeting activities carried out.

The Pearson correlation coefficient is 0,86629 , and the probability that the correlation coefficient is zero is 0,0001 . This is a fairly good correlation, with a very low probability of no correlation. Thus the hypothesis that there is a positive correlation between the nature of the business and the degree of budgeting used can probably be accepted.

\section{Correlation between background and training of CEO and degree of budgeting used}

Hypothesis 4 proposes that there is a positive correlation between the background and training of the CEO in budgeting and the degree of budgeting used. CEOs were asked whether

1. Prior to attaining their present position, they had experience in budgeting.

2. They had formal training or qualifications in accounting and budgeting.

To test the hypothesis, the number of positive responses to these questions was correlated with the number of budgeting activities carried out.

The Pearson correlation coefficient is 0,58232 , and the probability that the correlation coefficient is zero is 0,0001 . Again, this is a fairly good correlation, with a very low probability of no correlation. Thus the hypothesis that there is a positive correlation between the background and training of the CEO and the degree of budgeting used can probably be accepted.

\section{CEOs commitment to and participation in budgeting}

Three questions relate to the commitment and participation of CEOs in budgeting. Respondents indicate a commitment to and participation in budgeting by CEOs if they answer that:

1. The CEO is responsible for budgeting.

2. The CEO is fully comitted to budgeting systems.

3. The CEO plays an active role in drawing up and using budgets.

Hypothesis 5 proposes that CEOs of small manufacturing firms are committed to and participate in budgeting. To test this hypothesis, the proportion of responses indicating a commitment to and participation
Table 10 Analysis of commitment and participation

\begin{tabular}{lrrc}
\hline Question & Yes \% & No \% & $Z$ \\
\hline 1. CEO responsible for budgeting & 93,7 & 6,3 & 28,552 \\
2. CEO fully committed to budgeting & 60,3 & 39,7 & 3,342 \\
3. CEO actively involved in budgeting & 100,0 & 0 & $(\mathrm{x})$ \\
\hline
\end{tabular}

in budgeting by CEOs must be compared with the proportion indicating a lack of commitment and participation.

For the three questions, the proportion of Yes and No answers, and the $Z$ values, are as indicated in Table 10.

Thus the hypothesis is valid for all three questions. The $100 \%$ positive response to 'CEO plays an active role in drawing up and using budgets' indicates that the hypothesis may be accepted with a high degree of confidence that it is correct.

\section{Manager and staff commitment to and participation in budgeting}

Six questions relate to the commitment and participation of managers and staff in budgeting. Respondents indicate a commitment to and participation in budgeting by managers and staff if they answer that:

1. Managers and staff participate in setting budget goals.

2. Managers are committed to and involved in the budgeting system.

3. Budgets are perceived by managers and staff as a goal to achieve, to be rewarded.

4. It is important for motivation and commitment that managers and staff participate in drawing up budgets.

5. Participation in the budgeting process leads to improved performance by managers and staff.

6. The business is decentralized, and managers have a lot of responsibility.

Hypothesis 6 proposes that managers and staff of small manufacturing firms are committed to and participate in budgeting. To test this hypothesis, the proportion of responses indicating a commitment to and participation in budgeting by managers and staff must be compared with the proportion indicating a lack of this commitment and participation.

For the six questions, the proportion of Yes and No answers, the $Z$ values, are as indicated in Table 11 .

As the hypothesis is only valid for one of the six questions, the hypothesis cannot be accepted.

Table 11 Commitment and participation by staff

\begin{tabular}{lrrr}
\hline Question & Yes \% & No \% & \multicolumn{1}{c}{$Z$} \\
\hline 1. Managers and staff participate & 39,7 & 60,3 & $-3,342$ \\
2. Managers are committed and involved & 52,4 & 47,6 & 0,763 \\
3. Budgets are perceived as a goal to achieve & 47,6 & 52,4 & $-0,763$ \\
4. Participation is important for motivation & 55,6 & 44,4 & 1,789 \\
5. Participation leads to improved & & & \\
$\quad$ performance & 42,9 & 57,1 & $-2,277$ \\
6. Business is decentralized & 27,0 & 73,0 & $-8,224$ \\
\hline
\end{tabular}




\section{Benefits and problems of budgeting}

The benefits of budgeting perceived by respondents, and the percentage of companies perceiving them are indicated in Table 12.

The problems of budgeting perceived by respondents, and the percentage of companies perceiving them are indicated in Table 13.

\section{Conclusions based on the research}

The response rate of $36 \%$ is considered relatively good, which ensures sufficient responses on which to perform a

Table 12 Benefits of budgeting as perceived by respondents

\begin{tabular}{lc}
\hline Benefits & $\begin{array}{c}\text { \% of companies } \\
\text { perceiving that benefit }\end{array}$ \\
\hline 1. Helps control cash & 93,7 \\
2. Helps control business & 92,1 \\
3. Ensures regular planning & 87,3 \\
4. Provides daily operational guidelines & 71,4 \\
5. Helps set clear objectives & 69,8 \\
6. Allows performance evaluation & 61,9 \\
7. Pinpoints efficiencies and inefficiencies & 54,0 \\
8. Warns of potential problems & 54,0 \\
9. Forces periodic self-analysis & 47,6 \\
10. Communicates company objectives & 47,6 \\
11. Prevents crisis management & 46,0 \\
12. Helps make decisions based on fact & 41,3 \\
13. Assists motivation & 41,3 \\
14. Helps formalize plans & 39,7 \\
15. Reduces hasty decisions & 39,7 \\
16. Avoids problem fire fighting & 33,3 \\
17. Co-ordinates company activities & 31,7 \\
18. Forces regular accounting reports & 27,0 \\
19. Enables participation & 27,0 \\
20. Supports delegation & 14,3 \\
21. Forces proper organization structure & 14,3 \\
\hline
\end{tabular}

Table 13 Problems of budgeting as perceived by respondents

\begin{tabular}{lc}
\hline Problems & $\begin{array}{c}\text { \% of companies } \\
\text { perceiving that problem }\end{array}$ \\
\hline 1. Uncertainty of future & 84,1 \\
2. Uncertainty of sales & 79,4 \\
3. Inaccurate forecasts & 68,3 \\
4. Uncertainty of labour cost & 66,7 \\
5. Rapidly changing environment & 47,6 \\
6. Lack of understanding by managers & 41,3 \\
7. Takes too much time & 25,4 \\
8. Lack of commitment by managers & 20,6 \\
9. Too complicated and difficult & 19,0 \\
10. Lack of communication & 14,3 \\
11. Accounting reports always late & 6,3 \\
\hline
\end{tabular}

meaningful statistical analysis. All six industries chosen for the study are fairly evenly represented, suggesting that results should apply fairly broadly to all small manufacturing firms, particularly in the greater Johannesburg area. Companies range in age from two years to 35 years, with a fair distribution in between. Over half the companies are 15 years or less in age, which tends to support the widely held notion of the greater vulnerability of small businesses compared to large firms. The diverse sizes of the firms, as indicated by turnover, also suggest that results may be generalized to most small manufacturing firms. The middle category turnover had the highest frequency, indicating a fairly appropriate choice of turnover categories for this research. Thus, the background information indicates a good, diverse sample of small manufacturing firms, which should make the results of this research more generally applicable.

\section{Budgeting processes and procedures used}

Every respondent claims to carry out at least four of the ten budgeting activities, which confirms the literature's insistence on the vital necessity of budgeting for small firms. This implies that budgeting is generally accepted as an essential mangement technique in running small manufacturing firms. The average number of budgeting activities is seven, with very few firms performing only four or all ten activities. This shows fairly comprehensive use of the ten major budgeting activities suggested by the literature, and the practicality of these activities. A possible explanation for this is that the budgeting literature, by nature of the subject, is very practically oriented and experience-based. The subject does not lend itself to abstract speculation or philosophy. Writers put forward the normal activities which they have observed in practice. It thus does not come as much of a surprise that most activities mentioned by these writers are carried out by respondents. It is however satisfying to see evidence confirming the literature, particularly as much of the literature is not of South African origin.

The one activity all respondents carry out is cash budgeting. This indicates the widely accepted centrality and importance of cash management in the successful operation of business, particularly small firms. The other activities carried out by over $90 \%$ of respondents are sales forecasts, production budgets, raw material budgets and forecast income statements. This indicates the central pre-occupation of the small manufacturer how much will be sold, how much must be made and what will the profits look like. The importance accorded to raw materials over other costs indicates the general perception of raw materials as the most significant cost. This is confirmed by the widespread use of a mark-up on raw materials to cover other costs, with only $60,3 \%$ of respondents compiling overhead budgets. The preoccupation with raw material costs could indicate a weakness in small firm management, as success or failure depends on total cost control, including full overhead recovery. The relative importance of a labour expense budget (compiled by $74,6 \%$ of respondents) reflects the 
growing uncertainty of labour costs in a time of increased labour organization and militancy.

The least important activity seems to be balance sheet forecasts (compiled by $7,9 \%$ of respondents). This may indicate an inability by most small businessmen to appreciate fully the information contained in balance sheets, and an inability to conduct simple financial statement analyses. This inability was readily acknowledged by interviewees during the semi-formal interviews. Another explanation of the low incidence of balance sheet forecasts is that balance sheets are not perceived as containing particularly useful information. The use of historical cost information in times of high inflation, and the use of various depreciation and valuation methods, are often disparaged by practical businessmen who have no academic background. This would support the need for the accountancy profession to re-evaluate the usefulness of the information it routinely provides.

It is felt that the low incidence of compiling budgets for separate product lines ( $27 \%$ of respondents) is a major weakness in the effective management of most small firms. The literature strongly recommends breaking budgets down by product lines. Unless this is done, informed decisions on product mix and thus overall business strategy are impossible. In the semi-formal interviews, most firms accepted that this was a major weakness.

Budget periods range from one week for some activities to one year for others. For most companies, the average budget period for all their budgeting activities is one month. A few companies average a budget period of as short as between one and two weeks or as long as between three to six months. These results reflect the general short-term view of small manufacturers. Many tend to think only in terms of the lead time on raw materials, and no further. This over-emphasis on the short-term reflects the daily fight for survival of many small firms, which does not allow time for longer-term thinking. Paradoxically, this lack of strategic thinking may often lead to the demise of small firms, as the environment and technology suddenly change.

Consistent with the literature, budgeting in small manufacturing firms is largely an informal process. According to Merchant (1981) and Ackelsberg (1985), budgeting in small firms should not be too formal. All respondents describe their budgets as simple and flexible. Although most $(66,7 \%)$ draw up budgets in a regular, standardized manner, $60 \%$ put four or less budgeting activities in writing. Only one respondent carries out nine activities in writing.

The lack of strategic thinking is further confirmed by results which show that only $7,9 \%$ of respondents have clear, written, specific objectives for the business, and almost half have no clear, consistent strategy. In the literature, budgeting is perceived as the practical outcome of intensive self-analysis and strategic planning. However, this is not so in practice, and this lack of clear objectives and strategies is another area of managerial weakness in small manufacturing firms in South Africa.
It is felt that the main reason for this is lack of education and ignorance of the benefits of comprehensive strategic planning.

Although most companies responded that goals are loose and easy to obtain, this may be an inaccurate reflection due to the phrasing of the question. The optimum 'tight but attainable' level suggested by Kenis (1979) was often mentioned verbally by respondents, and the questionnaire made no provision for this. In addition, budgets are generally used for the guidance of the CEO, not for motivation of employees, and thus CEOs tend to set budgets at the level that they feel will actually be attained.

Despite the enthusiasm of the literature for the use of computers in small firm accounting and budgeting, only just over half the respondents run their accounting systems on computer. In contrast to Nickell and Seado (1986), who found $56 \%$ of small firms surveyed used computers for budgeting, only $25,4 \%$ of respondents in this survey use computers for budgeting. In addition, under half were positive in their perception of the contribution made by computers. This probably indicates the relative lack of computer sophistication of South African small manufacturers compared with those in other countries, particularly the United States. In the semi-formal interviews, those interviewees who used computers were extremely enthusiastic about their potential, whereas those who did not displayed a lack of appreciation of the range of hardware and software now available for small firms. This is another area with much potential for development amongst small firm owners in South Africa.

Just over a third of respondents carry out a continuous or rolling budgetary procedure, reflecting the greater expertise and time required for this procedure. However, this in itself is a positive result, that a third of respondents have the requisite skills and perceive the benefit of this procedure. In addition, as Welsch (1976) mentions, it is more appropriate for volatile industries than stable ones, which would lead to the expectation that this procedure applies to some firms.

Very few respondents $(14,3 \%)$ carry out any form of zero-base budgeting. This simplicity of the incremental approach makes this more appropriate than zero-base budgeting, which is time-consuming.

The need for flexible budgets is stressed in the literature, and all respondents use some form of flexible budgeting. This is a very positive result, as it indicates that small business owners use budgeting as a practical management technique, rather than discarding the budget if conditions change.

The absence of use of mathematical techniques for forecasting is probably a reflection of the education and training of small firm CEOs. However, assuming that at least a few respondents must have had the relevant training, it could indicate an inability to apply the abstract theories of a university degree to the practical problems of running a manufacturing firm.

The results with regard to the debate in the literature on whether budgets are used by small firms mainly for planning or mainly for control are inconclusive, with 
approximately half the respondents opting for each. However, the manner in which the question was phrased, compelling a choice of one or the other, may not be the most appropriate way of investigating this area.

Generally, the results indicate that a wide range of budgeting processes and procedures are used by small manufacturing firms in South Africa, but that there is room for much improvement in certain areas of budgeting.

\section{Perceived importance of budgeting}

Budgeting is considered very important by small manufacturers. Many interviewees in the semi-formal interviews commented that they 'could not run the business without it', or that 'budgeting is managing the business'. These results support the findings of previous research, and the stress on the importance of budgeting in the literature. This is a very positive sign, indicating a certain basic understanding and level of management skill amongst South African owners of small firms. It may be stated the CEOs of small manufacturing firms accept the importance of management techniques and practices, and do not believe in a totally 'set of the pants' management style. This is a strong justification for greater management education and training.

The one disturbing result is that most respondents do not feel it is important to set clear goals and objectives in order to motivate managers and staff. Kenis (1979) and Locke (1968) have found that goal-setting is important for motivation of employees. This may indicate a lack of understanding and ability by CEOs of small firms with regard to motivation of managers and staff. This concept is further explored in section 5.8. However, respondents showed significant support for the positive motivational effect of feedback to employees of results, which does display a certain insight into motivation.

\section{Perceived adequacy of accounting reports}

Accounting reports are generally perceived as adequate. Most respondents receive a monthly income statement and balance sheet. However, when compared with the recommendations in the literature with regard to accounting and performance reports, the results indicate a fairly simplistic approach by most companies to accounting reports. Only half of respondents have reports that compare actual results to budget, a third have reports tailored to fit the needs of the budgeting system, and very few $(12,7 \%)$ give reports to each manager relevant to his or her area of responsibility. Thus although small manufacturing CEOs are satisfied with their accounting reports, there may be much room for improvement in this area. This situation is probably a result of lack of understanding and education of CEOs of small manufacturing firms of the benefits and possibilities of more effective accounting reports. In addition, it may raise a question as to the level of advice and assistance rendered by professional accounting firms to their clients.

\section{Correlation between nature of the business and degree of budgeting used}

The degree of budgeting found in a firm is influenced by the nature of the business. This is consistent with the research of Cooley \& Pullen (1979), Merchant (1981) and others. It seems that the relevant aspects of the nature of the business which influence budgeting are size, stability and uncertainty of cash flow. The larger the firm (in terms of turnover, customers, orders, products and employees), the greater its stability (stable market, make-to-stock, make regular products), and the more uncertainty of cash flow (fluctuating foreign exchange rates), the greater the need for budgeting activities. A very small firm can be easily managed informally, without any systems. The larger it grows, the greater the need for systematic management.

Stability tends to increase the use of budgeting as expected results are more likely to occur, and the time spent on preparing budgets is perceived as beneficial. If the firm operates in a volatile manner, with results varying by large amounts each month, budgeting is not considered as useful. It becomes very difficult to estimate future results, and the time spent on drawing up budgets, which are then completely different from actual results, is considered wasted. Uncertainty of future cash flows however, enhance the need for budgets, as a range of future possibilities must be carefully calculated and provisions made accordingly. Cash must be monitored closely to ensure daily survival, and great uncertainty of cash flow requires more detailed preparation and planning. Steady cash flows can be retained mentally, and require little planning and budgeting.

\section{Correlation between background and training of CEO and degree of budgeting used}

The degree of budgeting found in small manufacturing firms is influenced by the background of the CEO. This is consistent with the literature, and is intuitively acceptable. A CEO who has had training or experience in budgeting would be more likely to implement budgeting than one who has not.

In small firms in particular, the personality and ability of the CEO strongly influences the management and operation of the firm.

One concept not investigated by the questionnaire was whether or not CEOs carried out budgeting activities as a continuation of systems in place prior to their appointment. This may provide an explanation for the degree of budgeting used in some firms.

\section{CEOs commitment to and participation in budgeting}

There is a complete involvement of CEOs of small manufacturing firms in budgeting. This is a very positive result, as the literature stresses the necessity for the CEO to give full support to budgeting if it is to be successful. This also confirms the perceived importance of budgeting, as CEOs feel it is sufficiently important to require their personal time and attention. 
This result also indicates the management style of many CEOs of small firms. The firm is often very centralized in structure, with the CEO making most decisions. In the semi-formal interviews, many interviewees, particularly in smaller firms, compiled budgets purely for their own use, without sharing these with their managers and staff. Discussions in the interviews, and these results, indicate a fairly authoritarian and paternalistic approach by CEOs in small firms. Many CEOs feel that they alone are capable of performing much of the necessary work in the small firm. This probably stems from the intimate involvement of most CEOs with their small businesses, as many have most of their personal assets invested in the business. They thus are extremely concerned to manage (and budget) the firm themselves, to ensure the best possible results. In addition this may reflect the inability of the small firm to afford capable, professional managers.

\section{Managers and staff commitment to and participation in budgeting}

Generally, there is little commitment to and participation in budgeting by managers and staff. This again reflects the centralized structure of the small manufacturing firm, with the $\mathrm{CEO}$ making most decisions.

This may reflect a lack of understanding amongst small firm CEOs of motivation principles. The literature and much research strongly supports the need for participation by employees in budgeting, to improve motivation and possibly performance. Small firm CEOs generally seem to be the 'boss' giving instructions rather than the leader guiding the team. This could be an indication of the chauvinism and paternalism still widely prevalent amongst South African managers. This lack of a participative management style in small firms is an area which requires much improvement in South Africa. It has implications both for business productivity and improvement, and in a wider societal sense.

The success of giving employees greater participation in some South African firms is an encouraging sign, which may lead to its more widespread use. However, resistance may be expected amongst small firm owners as in contrast to professional managers of large firms, they have great personal involvement in their organizations. Nevertheless, in line with world-wide trends, greater employee participation may well lead to improved productivity and profitability in small manufacturing firms in South Africa.

\section{Benefits and problems of budgeting}

The major benefits of budgeting are perceived to be its use in controlling cash, controlling the business and planning. The pre-eminent position of cash control once again re-inforces the concept of cash management as the major concern of small firms. Budgeting is basically a method of planning and control, which explains the high percentage of companies perceiving these as benefits of budgeting. The very low rankings of 'enables participation', 'supports delegation' and 'forces proper organization structure' is consistent with the above discussion on the lack of participation by employees in the management of small firms. Rather budgeting is seen as a means by which the CEO plans and controls the business.

The major problems of budgeting are seen as the uncertainty of future conditions. Budgeting is essentially a process of estimating the future, so it follows that the basic problem of budgeting is that the future is uncertain. Other problems suggested by the literature are not widely found amongst respondents.

\section{Recommendations}

Based on the findings of the study, several recommendations can be made which should prove useful to managers of small manufacturing firms:

1. Budgeting is an essential management tool and should be carried out by all firms. Budgeting should be comprehensive, but simple and flexible.

2. Small firm managers should concentrate on total cost control, not focus only on raw materials. Proper overhead recovery is essential.

3. Managers should develop greater ability to use and understand financial reports.

4. It is essential that budgets and reports be prepared for separate product lines.

5. Small firm managers should learn the concepts of strategic planning and management. There is a danger of ignoring long-term consequences with the overemphasis on short-term management.

6. There is much room for increased use of personal computers in small manufacturing firms, and managers should take the time to investigate the benefits of the inexpensive, high quality hardware and software currently available.

7. Accounting and performance reports can be greatly improved, with significant benefits for small firms.

8. A major area requiring improvement is the need for greater participation by managers and staff in the management of small manufacturing firms. Although this may be difficult to accept, it can provide important benefits to those firms willing to pioneer this development.

\section{Areas for further research}

The following are possible areas for future research which are related to the present study:

1. Various aspects of budgeting in small manufacturing firms may be investigated in detail, as this study is broad in scope.

2. Budgeting in service and retail firms may be examined, and compared with budgeting in manufacturing firms.

3. The education and training of small firm CEOs may be investigated, to provide insight into areas where education and training are most needed.

4. The influence of other factors on the degree of budgeting used, apart from the nature of the business and the background of the CEO, may be examined. 
5. The question of participation by managers and staff in the management of small firms may be researched.

\section{References}

Ackelsberg, R. 1985. Small Businesses Do Plan and It Pays Off. Long Range Plan., vol. 18, 5, 61 - 67.

Campbell, I.J. 1985. Budgeting : is it a technical or behavioural process? Manage. Acc., February, $66-70$.

Churchill, N.C. 1984. Budget Choice : Planning versus Control. Harv. Bus. Rev., July - August, 150 - 162.

Cooley, P.L. \& Pullen, R.T. 1979. Small Business Cash Management Practices. Am. J. Small Bus., October, 1 - 7.

Dearden, J. 1963. Profit-Planning Accounting for Small Firms. Harv. Bus. Rev., March-April, 89 - 97.

De Mong, R.F. \& Croll, D.B. 1981. Cost Accounting for the Small Business. Am. J. Small Bus., Spring, 48 - 57.

Dewhurst, J. 1983. Managerial decisions for small businesses. Manage. Acc., April, $24-25$.

Garrison, R.H. Managerial Accounting, 4th Edition. Plano: Business Publications.

Ibrahim, A.B. \& Goodwin, J.R. 1986. Perceived Causes of Success in Small Business. Am. J. Small Bus., Fall, 41 - 50.
Kenis, 1. 1979. Effects of Budgeting Goal Characteristics on Managerial Attitudes and Performance. Acc. Rev., LIV, 4, $707-721$.

Locke, E.A. 1968. Toward a Theory of Task Motivation and Incentives. Organ. Behav. Human Perform., May, 157 189.

Merchant, K.A. 1981. The Design of the Corporate Budgeting System : Influences on Managerial Behaviour and Performance. Acc. Rev., LVI, 4, 722 - 740.

Nickell, G.S. \& Seado, P.C. 1986. The Impact of Attitudes and Experience on Small Business Computer Use. Am. J. Small Bus., Spring, $37-48$.

Ray, G.H. 1974. Budgeting control case studies show ways to improved management. Manage. Acc., February, 30 - 34.

Robinson, R.B., Logan, J.E., Salem, M.Y. \& Pearce, J.A. 1986. Strategic versus Operational Planning in Small Retail Firms. Am. J. Small Bus., Winter, $7-20$.

Welsch, G.A. 1976. Budgeting : Profit Planning and Control, 4th Edition. Englewood Cliffs : Prentice-Hall.

Williams, J.A. 1985. Long Range Planning in Certain Small Engineering Concerns. Johannesburg : University of the Witwatersrand, (Unpublished MBA Research Report). 